\title{
Wilhelm Menke (1910-2007): a pioneer in chloroplast structure
}

\author{
Friederike Koenig • Georg H. Schmid
}

Received: 13 August 2008/Accepted: 26 November 2008/Published online: 17 January 2009

(C) Springer Science+Business Media B.V. 2009

Keywords Chloroplast structure - Thylakoids ·

Electron microscopy - Small angle X-ray scattering ·

Proteomics and lipidomics of the photosynthetic membrane . Immunology · Spectroscopy · Friedl Weber · Kurt Noack · Wilhelm Menke

Wilhelm Menke, former director of the Max-Planck-Institut für Züchtungsforschung in Cologne (1967-1978) and former head of the Botanical Institute of the University of Cologne (1961-1967), one of the very pioneers in photosynthesis research, died on January 4, 2007 at his home in Leverkusen, Germany, where he had lived in retirement in the vicinity of his daughter and her family. He was 96 years old.

Menke was born in 1910 in Paderborn and he also attended school in this medieval catholic town in Westphalia, Germany. From 1931 to 1938 he studied natural sciences in Münster, Graz and Berlin. Encouraged by Friedl Weber in Graz, Austria, he had started to chemically analyse chloroplasts there. However, he had to leave Austria because of political circumstances in 1933. He continued his work later in Berlin (Menke 1938a, b). During his time in the laboratory of Friedl Weber, who had introduced him to myelin figures from chloroplasts (Weber 1933), he performed the experiments for two publications on chloroplasts which appeared in Protoplasma (Menke 1934a, b). The supervisor of his doctoral thesis and his scientific mentor in Berlin was Kurt Noack at the institute

F. Koenig $(\bowtie)$

Universität Bremen, Fachbereich Biologie/Chemie,

Molekulare Pflanzenphysiologie, 28359 Bremen, Germany

e-mail: fkoenig@uni-bremen.de

G. H. Schmid

Voltmannstrasse 121B, 33613 Bielefeld, Germany

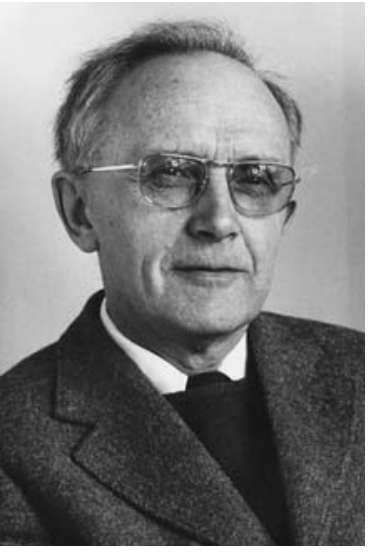

Wilhelm Menke, photograph courtesy of Archives of the MaxPlanck-Gesellschaft, Berlin-Dahlem

for plant physiology of Berlin University. In January 1938, Menke obtained the title "doctor of philosophy" and in April 1938, he was appointed as an assistant at this institute. Already in 1939, Menke had made an observation which made him tentatively conclude that the carotenoids in chloroplast preparations might be bound to protein (Menke 1940). In 1943, he obtained the habilitation in botany, the prerequisite for the position as a lecturer, which he obtained in April 1944, again in Berlin. His time in Graz and Berlin is described in detail in an article by Höxtermann (1991).

From July 1940 to September 1944, Wilhelm Menke served in Germany's armed forces. At the end of World War II, on May, 21st 1945 he was taken to the Soviet Union where he "had to work in a number of different scientific institutions of camp character on biophysical and biochemical questions until 1955". He was in the group together with Manfred von Ardenne and his sister Renata (see von Ardenne 1997); for further information see Oleynikov (2000). 
During his Berlin years, Menke was in contact with many clever and brilliant scientists like Kurt Noack, Otto Warburg, André Pirson, Hans Gaffron, Joseph Straub and Georg Melchers, some of whom became friends, others were to become colleagues later. Straub and Melchers helped him with the reintegration into the German academic system after he had been released from the Soviet Union in March 1955, after the end of the Stalin era. The experiments for Menke's first publication after the war were conducted in Georg Melchers' laboratory at the MaxPlanck-Institut in Tübingen where he was welcomed as a visiting scientist (Menke and Menke 1956). André Pirson remained a lifelong friend (Pirson 1994) and also Hans Gaffron was an occasional visitor to the institute in Menke's Cologne time.

In 1956, Menke moved to the Botanical Institute of Cologne University, first as an Assistant Professor and from 1958 on as Associate Professor. In 1961, he became full Professor and succeeded Joseph Straub in office as head of the Botanical Institute. In December 1967, he was appointed Director of the Max-Planck-Institut für Züchtungsforschung (Erwin-Baur-Institut; now also called the Max-Planck-Institute for Plant Breeding Research) in Cologne. He retired in summer 1978.

Back in Germany in 1955, Menke resumed his studies on the chemical composition, structure and function of the photosynthetic apparatus, mainly chloroplasts. Having had already seen lamellar structures in chloroplasts from Nicotiana, Spinacia and Aspidistra in the laboratory of Manfred von Ardenne in 1940 (Menke 1940) and also in Anthoceros (Menke and Koydl 1939) before World War II, he finally understood the inner structure of the chloroplast as a system of stacked and unstacked flattened vesicles surrounded by a membrane made of proteins and — besides pigments—lipids, mainly galactolipids, as A. Benson, J.F.G.M. Wintermans and R. Wiser were later able to demonstrate (1959). He called them thylakoids, a Greek term for "sac-like" $\delta v \lambda \alpha \chi o \varepsilon i \delta \eta \varsigma$ (Menke 1961). The original publication is in German (Menke 1961, translation in Gunning et al. 2006); however, many authors cite his review in this context, namely the 1962 article in Annual Review of Plant Physiology (Menke 1962).

Together with his research group, Menke made many efforts to elucidate the structure and chemical composition of chloroplasts. Thylakoids were investigated by means of small angle X-ray scattering (Kreutz and Menke 1960a, b). Pigments, lipids and proteins were isolated from thylakoids ("lamellar systems"), separated from each other, quantified and eventually characterized in their localization and function by means of specific antisera (for literature which he himself considered worth citing, see Menke 1990). The introduction of immunological methods into botanical research was one of his important contributions (Berzborn et al. 1966). In 1972, Menke elegantly summarized the results of his efforts concerning the elucidation of chloroplast structure in an article in the annual report of the MaxPlanck-Gesellschaft: "40 Jahre Versuche zur Aufklärung der molekularen Struktur der Chloroplasten” (Menke 1972).

Over the years, several investigations on thylakoid membrane structure, using specific antibodies directed against different chloroplast components, have shown that the thylakoid membrane also has a "mosaic" structure and is not made of two separate layers of protein (external) and lipids (internal), as was originally suggested by Menke $(1966 a, b)$. This was concluded from observations that certain components of the photosynthetic apparatus were accessible to antibodies from the stromal as well as from the luminal side of the thylakoid membrane (Koenig et al. 1977; Schmid et al. 1978).

Spectroscopy was one of Menke's scientific hobbies. Fork (1996) shows him together with C. Stacey French working with a derivative spectrophotometer, both smoking cigars. At the Botanical Institute of Cologne University and later at the Max-Planck-Institut für Züchtungsforschung in Cologne, we could always locate him by the smell of smoke from his cigar.

Menke's supervision provided several researchers with a solid education in spectroscopy, including Infra Red, IR (Menke 1970), Circular Dichroism, CD (Menke 1970; Menke and Hirtz 1973) and Optical Rotatory Dispersion, ORD. Until the very end of his professional life in 1978, he used to spend time in the laboratory, mainly recording spectra of plastid components, only interrupted by a nap in the afternoon or by an occasional Beethoven symphony or by painting in the evening, while the spectrometer would record the baseline! He had a profound knowledge of classical music.

Menke's stay in California in 1963 resulted in a publication on the effects of desiccation on the absorption properties of chloroplasts and algae, together with C. Stacey French and Warren L. Butler (Menke et al. 1965; also see Fork 1996) and in a lifelong attachment to chloroplast lipids. Menke seriously enjoyed his visit to Andrew A. Benson's laboratory in San Diego. He and Benson had a mutual respect for each other.

Wilhelm Menke was an extremely private person. What he wanted the outside world to know about himself he has published in his retrospective (Menke 1990) which he wrote at the invitation of Govindjee. There, he also mentioned his most important publications.

Despite the fact that Menke thought mainly at the level of molecular biology-molecular structure - terms which were not in fashion in the late 1960s and early 1970s, he was an excellent field biologist specializing in central European, mainly alpine plants. He was profoundly familiar with plants and plant life. From his out-door 
observations, interesting publications arose about the plastids of the parasitic orchid Neottia nidus-avis (Menke and Wolfersdorf 1968; Menke and Schmid 1976), the plastids in the green flowers of the orchid Aceras anthropophorum (Schmid et al. 1976) and last but not the least the plastids of the hornwort Anthoceros (Menke 1961). Menke's outdoor observations were the source and origin for his paintings.

Excellent botanical excursions led to different regions of the Alps, to Austria, but mostly to Switzerland. They were usually topped by a tour with rope and ice axe to a vegetation-less zone to which only botanists familiar with the high alpine environment were admitted. The others were supposed to botanize down in the valleys until the alpinists returned.

After the death of his wife Gertrud in 1974, and especially after his retirement in the summer of 1978, Menke spent much time travelling and painting, travelling most of the time to the Swiss Alps, where he used to spend greater parts of the summer hiking and climbing many of the overwhelming summits, frequently together with the world famous alpine guide Ulrich Inderbinen, who died in 2004 at the age of 104 years. He was especially familiar with the Valais, the region around Zermatt and Saas Fee, and also with Engadin. His favourite spot there was Pontresina.

Menke had always been interested in ancient architecture. On excursions with the authors, he never skipped a Romanesque church. He travelled alone to Sicily at the age of over 90 to fulfil an old dream: to see and study the ancient Greek temples there. He did not speak any modern language, besides German (and some English). However, he was confident that he would be understood, as he had learned both Latin and Greek at school. His profound knowledge of the Greek language gave him the background to coin the term "thylakoid" in 1961 (Menke 1961; see Gunning et al. 2006).

Wilhelm Menke was an absolutely independent thinker and a true pioneer in science (see Gunning et al. 2006), with his ideas and scientific initiatives often far ahead of his time. He did not hesitate to introduce any possible new method from other disciplines into his research, from chemistry as well as from physics. Among many other things we owe him the introduction of immunological methods into photosynthesis research (Berzborn et al. 1966). Moreover, he was a specialist in electron microscopy (see Menke 1961, 1963, among other papers) and in numerous spectroscopic methods. X-ray scattering experiments were as familiar to him as the application of the analytical ultracentrifuge. In his research group, he established any biochemical method available at the time. Under his leadership the members of his group became specialists in lipids as well as in membrane protein purification and characterization- "lipidomics" and "proteomics" one would possibly call this today.
In 1962, Menke was elected to membership of the German Academy of Sciences Leopoldina.

Wilhelm Menke's former students remember him as a most proficient and demanding teacher. Solid knowledge and understanding not only of botany, but also of chemistry as well as of physics were a prerequisite to be considered a participant of the botany courses he taught. Looking back, we see it as a privilege to have had the chance to learn from him. To work in his group was both a true challenge and an adventure.

A complete list of Menke's publications is available from the authors of this tribute.

Acknowledgments We thank U. Herzhoff, W. Eichenberger, E. Heinz and especially E. Höxtermann for information. The Archives of the Max-Planck-Gesellschaft, Berlin-Dahlem, are cordially thanked for documents and for the portrait. This tribute to Professor Wilhelm Menke was invited by Govindjee. We thank him and John Allen for editing this manuscript.

\section{References}

Benson AA, Wintermans JFGM, Wiser R (1959) Chloroplast lipids as carbohydrate reservoirs. Plant Physiol 34:315-317

Berzborn R, Menke W, Trebst A, Pistorius E (1966) Über die Hemmung photosynthetischer Reaktionen isolierter Chloroplasten durch Chloroplasten-Antikörper. Z Naturforsch 21b:1057-1059

Fork DC (1996) Charles Stacy French: a tribute. Photosynth Res 49:91-101. doi:10.1007/BF00029431

Gunning B, Koenig F, Govindjee (2006) A dedication to pioneers of research on chloroplast structure. In: Wise RR, Hoober JK (eds) The structure and function of plastids. Advances in photosynthesis and respiration, vol 23. Springer, Dordrecht, The Netherlands, pp xxiii-xxxi

Höxtermann E (1991) Photosynthese- und Stoffwechselforschung in der Geschichte der Botanik an der Berliner Universität (1810 bis 1945). Beiträge zur Geschichte der Humboldt-Universität zu Berlin Nr 27

Koenig F, Menke W, Radunz A, Schmid GH (1977) Localization and functional characterization of three polypeptides of the molecular weight 66000 . Z Naturforsch 32c:817-827

Kreutz W, Menke W (1960a) Strukturuntersuchungen an Plastiden I. Bestimmung der Dicke der Proteinlamellen aus der diffusen Röntgenkleinwinkelstreuung. Z Naturforsch 15b:402-410

Kreutz W, Menke W (1960b) Strukturuntersuchungen an Plastiden II. Röntgenographische Untersuchung wasserfreier isolierter Chloroplasten. Z Naturforsch 15b:483-487

Menke W (1934a) Chloroplasten-Studien. Protoplasma 21:279-298. doi:10.1007/BF01984502

Menke W (1934b) Chloroplasten-Studien II. Protoplasma 22:56-62. doi:10.1007/BF01608840

Menke W (1938a) Untersuchungen über das Protoplasma grüner Pflanzenzellen. I. Isolierung von Chloroplasten aus Spinatblättern. Z Physiol Chem 257:43-48

Menke W (1938b) Über den Feinbau der Chloroplasten. KolloidZeitschrift 85:256-259. doi:10.1007/BF01519274

Menke W (1940) Über den Zustand der Carotinoide in den Plastiden. Naturwissenschaften 12:31. doi:10.1007/BF01482462

Menke W (1961) Über die Chloroplasten von Anthoceros punctatus. Z Naturforsch 16b:334-336 
Menke W (1962) Structure and chemistry of plastids. Annu Rev Plant Physiol 13:27-44. doi:10.1146/annurev.pp.13.060162.000331

Menke W (1963) Zur Stereometrie der Heitz-Leyonschen Kristalle von Chlorophytum comosum. Z Naturforsch 18b:821-826

Menke W (1966a) The structure of chloroplasts. In: Goodwin TW (ed) Biochemistry of chloroplasts, vol 1. Academic Press, London, pp 3-18

Menke W (1966b) The molecular structure of photosynthetic lamellar systems. Brookhaven symposia in biology: No. 19: energy conversion by the photosynthetic apparatus, pp 328-340

Menke W (1970) Far ultraviolet circular dichroism and infrared absorption of thylakoids. Z Naturforsch 25b:849-855

Menke W (1972) 40 Jahre Versuche zur Aufklärung der molekularen Struktur der Chloroplasten. Jahrbuch der Max-Planck-Gesellschaft zur Förderung der Wissenschaften, pp 132-155

Menke W (1990) Retrospective of a botanist. Photosynth Res 25:7782. doi:10.1007/BF00035456

Menke W, Hirtz R-D (1973) The secondary structure of proteins in the thylakoid membrane. Z Naturforsch 28c:128-130

Menke W, Koydl E (1939) Direkter Nachweis des lamellaren Feinbaues der Chloroplasten. Naturwissenschaften 27:29-30

Menke W, Menke G (1956) Wasser und Lipide in Chloroplasten. Protoplasma 46:535-546. doi:10.1007/BF01248898
Menke W, Schmid GH (1976) Cyclic photophosphorylation in the mycotrophic orchid Neottia nidus-avis. Plant Physiol 57: 716-719

Menke W, Wolfersdorf B (1968) Über die Plastiden von Neottia nidus-avis. Planta 78:134-143. doi:10.1007/BF00406646

Menke W, French CS, Butler W (1965) Über die durch Trocknen bewirkten Absorptionsänderungen von Chloroplasten und Algen. Z Naturforsch 20b:482-487

Oleynikov PV (2000) German scientists in the Soviet Atomic Project. Nonprolif Rev VII:1-30

Pirson A (1994) Sixty years in algal physiology and photosynthesis. Photosynth Res 40:207-221. doi:10.1007/BF00034771

Schmid GH, Jankowicz M, Menke W (1976) Cyclic photophosphorylation and chloroplast structure in the labellum of the orchid Aceras anthropophorum. J Microsc Biol Cell 26:25-28

Schmid GH, Menke W, Radunz A, Koenig F (1978) Polypeptides of the thylakoid membrane and their functional characterization. $\mathrm{Z}$ Naturforsch 33c:723-730

Von Ardenne M (1997) Erinnerungen, fortgeschrieben. DrosteVerlag, Düsseldorf

Weber F (1933) Myelinfiguren und Sphärolithe aus Spirogyra-Chloroplasten. Protoplasma 19:455-462. doi:10.1007/BF01606241 